\title{
Physicochemical and Bacteriological Analysis of Sludge and Water Contaminated by Oil Spillage in Some Coastal Communities of Akwa Ibom State, Nigeria
}

\author{
Mercy Uwem Useh ${ }^{1,}$, , Pius Ikokoh ${ }^{1}$, Mary Sunday Dauda ${ }^{2}$, \\ Ogechukwu Philomena Onwuazor ${ }^{3}$, Danlami Uzama ${ }^{1}$ \\ ${ }^{1}$ Chemistry Advanced Research Centre, Sheda Science and Technology Complex, Kwali, Abuja, Nigeria \\ ${ }^{2}$ Chemistry Department, University of Abuja, Abuja, Nigeria \\ ${ }^{3}$ Biotechnology Advanced Research Centre, Sheda Science and Technology Complex, Kwali, Abuja, Nigeria \\ Email address: \\ usehmercy@gmail.com (M. U. Useh) \\ ${ }^{*}$ Corresponding author
}

\section{To cite this article:}

Mercy UwemUseh, Magnus Ifeanyi Osuagwu, Mary Sunday Dauda, Ogechukwu Philomena Onwuazor, Danlami Uzama. Physicochemical and Bacteriological Analysis of Sludge and Water Contaminated by Oil Spillage in Some Coastal Communities of AkwaIbom State, Nigeria. Advances in Applied Sciences. Vol. 2, No. 5, 2017, pp. 64-68. doi: 10.11648/j.aas.20170205.12

Received: October 4, 2016; Accepted: November 2, 2016; Published: September 26, 2017

\begin{abstract}
Crude oil contaminated sludge and water samples from four coastal communities (Ibeno, Onna, EsitEket and Eket) in Akwa Ibom State, Nigeria were analyzed to investigate the bacterial load and physicochemical parameters using standard pour plate method and standard analytical methods respectively. The $\mathrm{pH}$ values of both (sludge and water) samples as determined ranged from $5.14-5.22$ and $4.23-6.15$ respectively which indicated that the samples are acidic in nature. Other physicochemical parameters determined were: temperature, electrical conductivity, moisture content, organic matter, total alkalinity, TDS, TSS, total hardness, DO, BOD, sulphate, chloride, oil and grease. The bacteriological analysis of the water and sludge samples showed mean total bacterial count of $3.57 \times 10^{4}$ and $1.77 \times 10^{3} \mathrm{cfu} / \mathrm{ml}$ respectively. The mean coliform counts of water and sludge samples were $1.5 \times 10^{2}$ and $8.4 \times 10^{1} \mathrm{cfu} / 100 \mathrm{ml}$ respectively. The result of these analyses showed that most of these parameters did not meet the WHO recommended standards. Hence, the environment should beremediated with immediate effect to avoid further disaster.
\end{abstract}

Keywords: Crude Oil, Akwa Ibom, Bacteriological Analysis, Water, Sludge, Physicochemical Parameters

\section{Introduction}

Since commercial exploration of petroleum started in Nigeria in 1958, the oil industry in Nigeria has completely restructured the country's economy. However, this exploration has led to the pollution of lands and waterways [1]. Crude oil contamination from drilling processes creates problems that disrupt the lives of people living in close proximity to oil camps, wells, pumping stations, and pipelines. People living on oil-rich sites around the world are subjected to contamination of drinking water, topsoil, and livestock due to toxic pollution that results from the oil extraction process. In some contaminated sites, serious illnesses resulting from exposure have been documented. Multiple studies have been done that compared cancer rates of people living in close proximity to oil contaminated sites to those who live in unaffected regions. Most of these studies conclude that there is a correlation between the proximity of the subject to the contamination and an increased cancer rates. The water, soil and air have been severely tainted by petroleum pollutants $[1,2]$.

The devastating consequences of oil spill especially in the Niger Delta region of Nigeria together with its eventual hazards on aerial, terrestrial and aquatic environs manifest as an irreversible chain effect on both the biodiversity and human safety. The Niger Delta covers approximately 70,000 $\mathrm{km}^{2}$ and is home to over 40 ethnic groups. Hundreds of thousands of these people are affected by the resulting oil contamination near their homes. Especially affected are some $80 \%$ of the region's inhabitants who have little money and 
rely on fishing and agriculture to survive. The agricultural lands have become less productive, the creeks and fishing waters have become extremely vulnerable to damaging effects of oil pollution. Some of the major factors associated with accelerating pace of oil spill are accidental damage of pipes and tankers $(50 \%)$, sabotage $(28 \%)$, oil production operations $(21 \%)$ and poor maintenance of infrastructure (1\%) [3].

Many locals in the region attest to environmental damage that allegedly developed as a result of the leak. Oil spills in the delta's creeks have been left to fester for decades, polluting the air, soil, and water of impoverished communities. Nigeria sees its future output growth largely in offshore fields and does not want spills there to compound its environmental woes. The Nigerian Environmental Rights Action group issued a demand for N51 billion (\$100 Million) from Exxon Mobil in Nigeria for their failure to compensate fisher men within the coastal areas who suffered devastating losses due to the oil company's exploration activities and major oil spills. Thick balls of tar have also been sighted washed upon the shore line as well as oil slicks. The spill has only exacerbated the already growing problem of pollution in the Delta. The Nigerian government estimates there were over 7,000 spills, large and small, between 2000 and 2012, according to the BBC. Vast swathes of the Delta have been seen covered with tar and stagnant lakes of crude due to oil spills of the past [4].

Environmental Rights Action / Friends of the Earth Nigeria (ERA/FoEN) visited Ibeno Community on the Atlantic coastline of Akwa Ibom State in 2014, following reports of an oil spill from the Qua Iboe Oil Fields operated by Mobil Producing Nigeria (MPN). Two major oil spills were said to have also occurred within the Qua Iboe Oilfield.It has been a string of woes for the coastal communities. Though MPN, an affiliate of Exxon Mobil had in a statement admitted its facility caused the spill which it put at some 200 barrels of crude oil, community members told ERA/FoEN field monitor that the latest incident is one among several spills that they said, was injurious to aquatic life which they depend on for their livelihood. During the visit, members of the community were seen in groups at the coastline bemoaning what had befallen them and its effect on their fishing vocation. ERA/FoEN monitor observed massive crude oil deposits on the shoreline as well as fishing boats and nets stained with crude oil deposits [5].

Crude oil if spilled into the water and soil spreads over a wide area forming a slick and the environment immediately begins to undergo a variety of physical, chemical and biological changes including evaporation of high volatile fractions, dissolution of water-soluble fractions, photochemical oxidation, emulsification, microbial degradation and sedimentation. Water pollution occurs when crude oil spills directly or indirectly into the water body resulting in unfavorable condition in which safety and welfare of any living organism is endangered. Several civil unrests due to environmental degradation from oil exploration is reported in the tropics, especially in Ibeno,
Onna, Esit Eket and Eket LGAs of Akwa Ibom State, Nigeria, therefore the release of crude oil into the environment by oil spill is receiving worldwide attention [6]. Since the commencement of oil exploration activities in these areas, only scanty data are available for levels of chemical pollution brought about by these activities. Secondly, inspites of various efforts to bring development to all parts of the LGAs by the government, there are immense difficulties arising from the absence of a coherent body of information and data on which to base intervention decisions. Thus the main aim of this research is to investigate the physicochemical properties and bacterial load of crude oil contaminated water samples and sludge collected from Ibeno, Onna, Esit Eket and Eket LGAs of Akwa Ibom State, Nigeria.

\section{Materials and Methods}

\section{Sample Collection, Preparation and Preservation}

A total of twenty four (24) samples were used for the present study. Twelve (12) sludge samples were randomly collected using soil auger from four (4) oil-impacted areas; Stubbs Creek in Ibeno LGA, Ikot Ebidang in Onna LGA, Etebi in Esit Eket LGA and Esuk Odio in Eket LGA all in Akwa Ibom State, Nigeria. The samples were taken from three (3) locations in each site, stored in sealed polythene bags properly labeled and transported to the laboratory for pre-treatment and analyses. The sludge samples were airdried for two weeks, rolled manually, mixed and sieved with $2 \mathrm{~mm}$ mesh to remove stones and debris [7]. Twelve (12) water samples were collected in the said areas in well-labeled polyethylene containers which were prewashed and soaked in $1 \mathrm{M} \mathrm{HNO}_{3}$ for 24 hours and later rinsed with deionised water. The samples were transported to the laboratory in a cooler of ice to ensure rapid cooling and were protected from direct sunlight during transportation. Uncontaminated samples were used as control. They were further preserved in the refrigerator prior to analyses [8].

\section{Physicochemical Analysis}

Soil $\mathrm{pH}$ was determined for all samples by using 1:2 slurry of $10 \mathrm{~g}$ sludge sample with $20 \mathrm{ml}$ deionised water. After 10 minutes, $\mathrm{pH}$ was determined using a digital $\mathrm{pH}$ meter and electrical conductivity measurement was determined at $25^{\circ} \mathrm{C}$ using conductivity meter (Systronics-304). The sludge moisture content was determined by gravimetric method in which $2.0 \mathrm{~g}$ of each sample was dried in an oven at $105^{\circ} \mathrm{C}$ to constant weight. The difference in weight gives the moisture content. Organic matter was determined using Loss-OnIgnition (LOI) method which involved the heated destruction of all organic matter in the sludge sample. A known weight of sample was placed in a ceramic crucible which was then heated to $400^{\circ} \mathrm{C}$ overnight. The sample was then cooled in a desiccator and weighed. Organic matter content was calculated as the difference between the initial and final sample weights divided by the initial sample weight times 
$100 \%$. Total alkalinity was determined by titrimetric method in which $100 \mathrm{ml}$ of distilled water was added to $20 \mathrm{~g}$ of the sludge sample and stirred for one hour at regular intervals using magnetic stirrer. The suspension so obtained was filtered and the filtrate was titrated with a standard solution of $\mathrm{HCl}$ using phenolphthalein and methyl orange as indicators. Sulphate was determined by gravimetric method which involved the use of excess amount of barium chloride solution. Sulphate was precipitated as barium sulphate and the precipitate was filtered, washed, dried, ignited and weighed. Chloride was determined by Mohr's method in which the filtrate was titrated with a standard solution of silver nitrate using potassium chromate as indicator. Then oil and grease by gravimetric method also.

The temperature of the water samples were determined insitu using the mercury-in-glass thermometer. $\mathrm{pH}$ was determined using a Pocket Digital $\mathrm{pH}$ Meter and electrical conductivity was measured at $25^{\circ} \mathrm{C}$ using conductivity meter (Systronics-304). All these were recorded at the site of sample collection $[7,8]$. Other parameters carried out in the laboratory include: chloride by Argentometric method as stated above, total hardness was determined by titrimetric method in which $1 \mathrm{ml}$ of a buffer solution was added to 50 $\mathrm{ml}$ of each of the water samples using Eriochrome black T$\mathrm{NaCl}$ mixture as indicator. When the sample turned red, it was titrated with EDTA solution until the solution turned blue, then hardness was calculated in terms of $\mathrm{mg}$ of $\mathrm{CaCO}_{3} / \mathrm{L}$. Total dissolved solids was determined by gravimetric methods, alkalinity by titrimetric method in which $100 \mathrm{ml}$ of the sample was used following the same procedure as stated above, total suspended solids was determined by filtration method, dissolved oxygen was determined by Winkler's method in which 100 ml glassstoppered conical flask each was filled with the water sample and was treated with $1 \mathrm{ml}$ each of alkaline $\mathrm{KI}$ and $\mathrm{MnSO}_{4}$ solution. The contents were thoroughly shaken and the precipitates were allowed to settle for sometimes. $1 \mathrm{ml}$ of concentrated $\mathrm{H}_{2} \mathrm{SO}_{4}$ was added and titrated with sodium thiosulphate solution using starch as indicator. Biochemical oxygen demand was determined by APHA method which involved the measurement of the oxygen concentrations of the samples immediately and that after incubating it for five days [8].

\section{Bacteriological Analysis}

The total bacterial count was determined by pour plate technique using standard methods. Nutrient agar medium was used for the enumeration of bacteria in the samples. Total coliform count was determined by MPN index method by employing 3-3-3 regimen using macConkey broth and negative result was indicated since there was no acid and gas production on incubation at $37^{\circ} \mathrm{C}$ for 48 hours [9].

\section{Statistical Analysis}

All the determinations were conducted in tripricates and data generated were analyzed statistically by one-way analysis of variance (ANOVA) technique using (SPSS) 16.0.

\section{Quality Assurance}

To ensure that the results were accurate, reliable and reproducible, strict adherence to the standard operating procedures and precautions were ensured at all levels. Also, reagent blank determinations were used to correct the instrument readings.

\section{Results and Discussion}

The results of the analyses are presented in tables 1 to 3 . From tables 1 and 2, the $\mathrm{pH}$ of the sludge samples ranged from 5.14-5.22 with a mean value of $5.18 \pm 0.04$ while that of water samples ranged from 4.23-6.15 with a mean value of $5.08 \pm 0.84$ which are below the WHO standard range of 6.50 to 8.50 . These $\mathrm{pH}$ values indicated that the samples are acidic which is not good for human consumption. It equally showed a slight decrease from acceptable fish/aquatic lives survival limit [10]. From Table 1, the moisture content ranged from 0.2 to $1.0 \%$ with an average value of $0.60 \pm 0.34 \%$. Therefore, the weight of the sludge samples used for the digestion was taken as absolute value, since percentage moisture content makes practically no difference [11]. From table 1, the organic matter is relatively high ranging between 5.17 and $8.24 \%$. This could be attributed to the presence of the crude oil samples available in the sorption process. Also, the presence of crude oil on the soil medium created an anaerobic condition within the medium. This condition led to the death of most aerobic micro organisms which formed part of the organic substances that added to the organic matter content of the soil. The $\%$ organic matter obtained here was within the ranges observed for some tropical soil type [12, $13,14,15]$.

The electrical conductivity recorded for the sludge samples ranged from $0.23-0.41 \mu \mathrm{s} / \mathrm{cm}$ with an average value of $0.31 \pm 0.08 \mu \mathrm{s} / \mathrm{cm}$ while that of the water samples ranged from $0.24-0.57 \mu \mathrm{s} / \mathrm{cm}$ with an average value of $0.45 \pm 0.14 \mu \mathrm{s} / \mathrm{cm}$. These values were below the recommended WHO standard [16]. The total alkalinity indicates the capacity of the sample to neutralize acids. A sample may be alkaline due to the presence of free $\mathrm{OH}^{-}$ions and also certain salts like carbonates, bicarbonates, borates and silicates which produce alkalinity because of hydrolysis. However, the contribution of carbonates and bicarbonates is a major source of alkalinity. The average alkalinity values of $0.83 \pm 0.16$ and $0.50 \pm 0.12$ $\mathrm{mg} / \mathrm{l}$ were recorded for the sludge and water samples respectively. These values were below the highest desirable level of $200 \mathrm{mg} / \mathrm{l}$ recommended by WHO [16].

Sulphates are found appreciably in all natural waters, particularly those with high salt content. Besides industrial pollution and domestic sewage, biological oxidation of reduced sulphur species also adds to sulphate content. Soluble in water, it imparts hardness with other cations. Sulphate causes scaling in industrial water supplies, and 
odour and corrosion problems due to its reduction to hydrogen sulphide. The presence of chlorides in natural waters can mainly be attributed to dissolution of salt deposits in the form of ions $\left(\mathrm{Cl}^{-}\right)$. It is the major form of inorganic anions in water for aquatic life. High chloride content has a deleterious effect $[17,18]$. The concentrations of major anions (sulphate and chloride) in the sludge samples obtained ranged from $10.48-15.13 \mathrm{mg} / \mathrm{l}$ and $264-318 \mathrm{mg} / \mathrm{l}$ with mean concentrations of $12.21 \pm 2.02 \mathrm{mg} / 1$ and $295.75 \pm 23.75 \mathrm{mg} / 1$ respectively. The chloride concentration of the water samples ranged from 191-285 $\mathrm{mg} / \mathrm{l}$ with an average value of $252.25 \pm 42.2 \mathrm{mg} / \mathrm{l}$. It is obvious that the chloride concentration at each site exceeds the WHO permissible limit except the water sample from Eket site.

Table 1. Results of some physicochemical parameters of the sludge samples.

\begin{tabular}{|c|c|c|c|c|c|c|}
\hline PARAMETERS & IBENO & ONNA & ESITEKET & EKET & MEAN \pm S.D & RANGE \\
\hline $\mathrm{pH}$ & 5.16 & 5.19 & 5.22 & 5.14 & $5.18 \pm 0.04$ & $5.14-5.22$ \\
\hline Conductivity $(\mu \mathrm{s} / \mathrm{cm})$ & 0.25 & 0.23 & 0.41 & 0.35 & $0.31 \pm 0.08$ & $0.23-0.41$ \\
\hline Moisture content (\%) & 0.70 & 1.00 & 0.20 & 0.50 & $0.60 \pm 0.34$ & $0.20-1.00$ \\
\hline Organic matter $(\%)$ & 6.83 & 8.24 & 5.17 & 6.62 & $6.72 \pm 1.26$ & $5.17-8.24$ \\
\hline Total alkalinity $(\mathrm{mg} / \mathrm{l})$ & 0.72 & 1.06 & 0.75 & 0.80 & $0.83 \pm 0.16$ & $0.72-1.06$ \\
\hline Sulphate (mg/l) & 11.54 & 15.13 & 10.48 & 11.67 & $12.21 \pm 2.02$ & $10.48-15.13$ \\
\hline Chloride (mg/l) & 309 & 292 & 318 & 264 & $295.75 \pm 23.75$ & 264-318 \\
\hline
\end{tabular}

Table 2. Results of some physicochemical parameters of the water samples.

\begin{tabular}{|c|c|c|c|c|c|c|}
\hline PARAMETERS & IBENO & ONNA & ESITEKET & EKET & $\operatorname{MEAN} \pm$ S.D & RANGE \\
\hline $\mathrm{pH}$ & 4.23 & 6.15 & 5.31 & 4.62 & $5.08 \pm 0.84$ & $4.23-6.15$ \\
\hline Conductivity $(\mu \mathrm{s} / \mathrm{cm})$ & 0.24 & 0.57 & 0.48 & 0.51 & $0.45 \pm 0.14$ & $0.24-0.57$ \\
\hline Temperature $\left({ }^{\circ} \mathrm{C}\right)$ & 29.5 & 29.8 & 29.6 & 29.9 & $29.7 \pm 0.18$ & $29.5-29.9$ \\
\hline $\mathrm{Cl}^{-}(\mathrm{mg} / \mathrm{l})$ & 274 & 285 & 259 & 191 & $252.25 \pm 42.2$ & $191-285$ \\
\hline Total hardness (mg/l) & 147 & 152 & 135 & 139 & $143.25 \pm 7.68$ & $135-152$ \\
\hline TDS (mg/l) & 1659 & 1549 & 1582 & 1594 & $1596 \pm 46.12$ & $1549-1659$ \\
\hline Total alkalinity $(\mathrm{mg} / \mathrm{l})$ & 0.56 & 0.32 & 0.55 & 0.58 & $0.50 \pm 0.12$ & $0.3-0.58$ \\
\hline DO (mg/l) & 1.77 & 1.59 & 1.92 & 1.53 & $1.70 \pm 0.18$ & $1.53-1.92$ \\
\hline BOD (mg/l) & 194 & 188 & 190 & 197 & $192.25 \pm 4.03$ & $188-197$ \\
\hline Oil and grease (mg/l) & 956 & 563 & 748 & 759 & $756.5 \pm 160.5$ & $563-956$ \\
\hline
\end{tabular}

Table 3. Bacteriological analysis results.

\begin{tabular}{llll}
\hline SITES & SAMPLE & TOTAL BACTERIAL COUNT (cfu/ml) & TOTAL COLIFORM COUNT (cfu/100mI) \\
\hline IBENO & Water sample & $1.05 \times 10^{4}$ & $2.8 \times 10^{1}$ \\
ONNA & Water sample & $6.74 \times 10^{4}$ & $4.0 \times 10^{2}$ \\
ESIT EKET & Water sample & $2.50 \times 10^{4}$ & $3.5 \times 10^{1}$ \\
EKET & Water sample & $4.00 \times 10^{4}$ & $1.4 \times 10^{2}$ \\
MEAN & & $3.57 \times 10^{4}$ & $1.5 \times 10^{2}$ \\
IBENO & Sludge sample & $1.25 \times 10^{3}$ & $1.7 \times 10^{1}$ \\
ONNA & Sludge sample & $2.11 \times 10^{3}$ & $1.35 \times 10^{2}$ \\
ESIT EKET & Sludge sample & $2.41 \times 10^{3}$ & $1.05 \times 10^{2}$ \\
EKET & Sludge sample & $1.30 \times 10^{3}$ & $8.0 \times 10^{1}$ \\
MEAN & & $1.77 \times 10^{3}$ & $8.4 \times 10^{1}$ \\
\hline
\end{tabular}

Total hardness is the sum of calcium and magnesium concentrations, both expressed as $\mathrm{CaCO}_{3}$ in $\mathrm{mg} / \mathrm{L}$. The total hardness of the water samples ranged from 135 to $152 \mathrm{mg} / \mathrm{l}$ with a mean concentration of $143.25 \pm 7.68 \mathrm{mg} / \mathrm{l}$ indicating that the water is hard [19]. Waters with high dissolved solids generally are of inferior palatability [20]. The total dissolved solids of the water samples ranged from 1549-1659 mg/l which is very high while the total suspended solids ranged from 1471-1508 $\mathrm{mg} / \mathrm{l}$ with an average concentration of $1485 \pm 16.39 \mathrm{mg} / \mathrm{l}$. Water with high-suspended solids as seen here is unsatisfactory for bathing, industrial and other purposes.

Oxygen dissolved in water serves as an indicator of the physical, chemical and biological activities of the water body and it is considered to be the major limiting factor in water bodies with organic materials [21]. The average DO recorded was $1.70 \pm 0.18 \mathrm{mg} / \mathrm{l}$ which was very minimal and this could be attributed to the consumption of dissolved oxygen by bacteria feeding on the spilled hydrocarbons which also contributes to the death of fish. Biological Oxygen Demand (BOD) test is used to determine the pollution load of water samples $[21,22]$. The BOD ranged from $188-197 \mathrm{mg} / \mathrm{l}$ with a mean concentration of $192.25 \pm 4.03 \mathrm{mg} / \mathrm{l}$ which signified that water is greatly polluted. From table 1 and 2, the mean concentrations of oil and grease in the soil samples is $15842 \pm 295.8 \mathrm{ml} / \mathrm{l}$ while that of the water samples is $756.5 \pm 160.5 \mathrm{mg} / \mathrm{l}$. This showed that the environment is highly contaminated. The bacteriological analysis of the water and sludge samples showed total bacterial count of $3.57 \times 10^{4}$ and $1.77 \times 10^{3} \mathrm{cfu} / \mathrm{ml}$ respectively. The mean coliform counts of water and sludge samples were $1.5 \times 10^{2}$ and $8.4 \times 10^{1} \mathrm{cfu} / 100 \mathrm{ml}$ respectively. These values are very 
much higher than the WHO standards for drinking water.

\section{Conclusion}

Over the years, several statistical models have been used to make estimates of the burden of environmental degradation. Understanding the magnitude and future trends of the oil spillage is necessary prerequisite for proper planning and mobilization of resources for its clean-up and remediation. The results showed marked variation in characteristics in all the 4 locations or sites. The degree of contamination for the four identified polluted sites has been estimated following a rigorous quality control procedure. This work is recommended to all involved in the commendable work of environmental safety and sustainability especially cleaning up and remediation of oil spill polluted sites in the Niger Delta Region of Nigeria.

\section{References}

[1] Nwilo, P. C., Badejo, O. T., 2005. Impacts and Management of Oil spill Pollution along the Nigerian coastal area.

[2] Benka-Cooker, M. O. and J. A. Ekundayo, (1995). Effects of oil spill on soil physiochemical properties of a spill site in the Niger Delta Nigeria. Environ. Monitoring Assessment, 36: $93-$ 109.

[3] Kayode, J., Oyedeji, A. A., Olowoyo, O., (2010). Evaluation of the Effect of Pollution with Spent Lubricating oil on the Physical and Chemical Properties of Soil. Pacific Journal of Science and Technology 10(1), 387-391.

[4] Edema, N. E. (2009). Total salinity of the water soluble fraction (WSF) of Ogini well-head crude oil before and after exposure to Azolla Africana Devs. Nigerian Journal of Botany. 22(2):239-246.

[5] Pepper, L. L., Gerbal, C. P., Brusseau, M. L., (1996). Pollution Science, Academic Press.

[6] Inoni O. E, Omotor D. G. and Adun F. N. (2006). The effect of oil spillage on crop yield and farm income in Nigeria. J. Central Eur. Agric. 7(1):41-49.

[7] Nelson, D. W. and Sommers, L. E.(1996). Methods of Soil Analysis. $2^{\text {nd }}$ ed. Vol. 2, London: MadisonInc.

[8] APHA (American Public Health Association) (2003) Standard Methods for the Examinations of Water and Wastewater, $19^{\text {th }}$ edition, Washington DC.

[9] Franco, I., M. Contin, G. Bragato and M. De Nobili, (2004). Microbiological resilience of soils contaminated with crude oil. Geoderma, 121:17-30.
[10] Andrade, M. L. E. F. Covelo, F. A. Vega and P. Marcet, (2004). Effect of the prestige oil spill on salt marshy soils on the coast of Galicia North western Spain. J. Environ. Qual., 33: $2103-2110$.

[11] Ogboghodo, I. A., E. K. Iruaga, I. O. Osemwota and J. U. Chokor, (2004). Anassessment of the effects of crude oil pollution on soil properties, using two crude types-Forcados light and escravos light. J. Environ. Monitoring Assessment, 96:143-152.

[12] Dane, J. H, Topp, G. C. (2012). Methods of Soil Analysis, Part 4. Physical Methods. SSSA, Inc., Madison, WI, pp. 241-254.

[13] Odu, C. T., (1997). Microbiology of soils contaminated with petroleum hydrocarbons Natural rehabilitation and reclamation of soil affected. Inst. Petroleum@Technol., Publ. 1, 77-105.

[14] Marinescu, M., Toti, M., Tanase, V., Plopeanu, G., Calciu, I., Marinescu, M., (2001). The effects of crude oil pollution on physical and chemical characteristics of soil. Resaerch Journal of Agricultural Science, 43(3), 125-129.

[15] Trivedy, R. K. and Goel P. K. (2008): Chemical and biological methods for water pollution studies, Environmental Publication, Karad, Maharashtra.

[16] WHO (World Health Organization). WHO International Standards for Drinking Water, (1998), 10-15.

[17] Bennett, P. C., Siegel, D. I., Baedecker, M. J., and Hult, M. F., (1993), Crude oil in a shallow aquifer, 1-Aquifer characterization and hydrogeochemical controls on inorganic solutes: Applied Geochemistry, v. 8, p. 529-549.

[18] Dillard, L. A., Essaid, H. I., and Herkelrath, W. N., (1997), Multi phase flow modeling of a crude-oil spill site with a bimodal permeability distribution: Water Resources Research, v. 33 , p. $1617-1632$.

[19] Eganhouse, R. P., Baedecker, M. J., Cozzarelli, I. M., Aiken, G. R., Thorn, K. A., and Dorsey, T. F., (1993), Crude oil in a shallow sand and gravel aquifer, II-Organic geochemistry: Applied Geochemistry, v. 8, p. 551-567.

[20] Essaid, H. I., Bekins, B. A., Godsy, E. M., Warren, E., Baedecker, M. J., and Cozzarelli, I. M., (1995), Simulation of aerobic and anaerobic biodegradation processes at a crude oil spill site: Water Resources Research, v. 31, p. 3309-3327.

[21] Landon, M. K., and Hult, M. F., (1991), Evolution of physical properties and composition of a crude oil spill, in Mallard, G. E., and Aronson, D. A., eds., U.S. Geological Survey Toxic Substances Hydrology Program, Monterey, California, March 11-15, 1991: U.S. Geological Survey Water-Resources Investigations Report 91-4034, p. 641-645.

[22] Smith, S. E., and Hult, M. F., (1993), Hydrogeologic data collected from a crude oil spill site near Bemidji, Minnesota, 1983-91. 